\title{
Introduction to the special issue on agricultural productivity growth: a closer look at large, developing countries
}

\author{
Keith Fuglie $・$ David Schimmelpfennig
}

Published online: 19 January 2010

(C) US Government 2010

Productivity is a centrally important issue in economics because it is one of the principal determinants of economic welfare. Analysis of agricultural productivity has a special place in agricultural economics because of the large dependency on natural resources in this sector and periodic concerns that we may be reaching limits in natural resource capital available for food production. The sharp rise in agricultural commodity prices over 2007-2008 elevated concerns of global supply and demand imbalances-that the rising demand for grain from the increasingly larger and wealthier world population and from the newly emerging biofuel industry was outstripping the ability of farmers to raise production, thus leading to a permanent era of higher real agricultural prices. ${ }^{1}$

This special issue of the Journal of Productivity Analysis is partly motivated by these recent global developments, and also by the realization that long-run trends in agricultural productivity have implications beyond the recent commodity price crisis, including poverty reduction in developing countries and global environmental challenges like climate change. Our focus in this issue is on agricultural productivity change in the global economy, with particular attention to large agricultural producers outside of the OECD countries, namely, China, India, Indonesia, and collectively the transition economies of the former Soviet Union and Eastern Europe. Our reasons for focusing on these areas are two fold: first, these are large

The views expressed in this issue are not necessarily those of the Department of Agriculture.

K. Fuglie · D. Schimmelpfennig $(\bowtie)$

Economic Research Service, US Department of Agriculture, 1800 M Street NW, rm. S4179, Washington, DC 20036, USA

e-mail: des@ers.usda.gov agricultural producers and supply prospects here will have major consequences for the global food economy; and second, the policies and institutions needed to sustain agricultural productivity growth, such as research and development systems and efficient markets, are not as well established, and thus the prospects for future growth less certain, than in modern industrialized nations.

Recent assessments of trends in global agricultural productivity present a mixed picture. One recent analysis of agricultural yields finds a declining rate of growth for major crops and for global agriculture as a whole and attributes the yield decline to a secular decline in the rate of growth in agricultural research spending resulting in less new technology (Alston et al. 2009). But changes in land or labor productivity could be due to either changes in capital intensification or to changes in total factor productivity (TFP), and the rate of TFP growth gives a better metric of technical change. Other recent studies that have constructed TFP indices for global agriculture do not find evidence of a slowdown in global agricultural TFP growth (Fuglie 2008; Ludena et al. 2007). Nonetheless, all of these studies show wide variation in productivity growth among countries, over time, and across commodities or commodity groups. Divergent productivity patterns are especially pronounced among developing countries and the transition economies of the former Soviet block.

Below, we first provide an overview of the papers in this volume and then we draw upon this work and other recent studies to provide a comparative assessment of the sources of long-run agricultural productivity growth in three of the

\footnotetext{
${ }_{1}$ Interested readers are referred to a special issue of Agricultural Economics (Vol. 39 supplement, December 2008), for an excellent set of articles reviewing the state of knowledge on the causes and consequences of the recent global food price crises.
} 
largest agricultural economies in the developing world: China, India and Indonesia. The findings highlight the important role of institutional and policy reforms as well as investments in agricultural research in overcoming natural resource constraints and sustaining productivity growth in agriculture.

\section{Agricultural productivity growth in developing and transition economies}

The papers in this volume employ a variety of methods to assess agricultural productivity growth in the global economy and for individual countries. In the first paper following this introduction, Evenson and Fuglie take on the rather ambitious task of measuring and comparing agricultural TFP growth for the entire world, as well as individual countries and regions, between 1961 and 2006. ${ }^{2}$ They employ a Solow-type growth accounting framework to compare long-run TFP growth (but not TFP levels) across countries. Further, they develop indexes of "technology capital" and examine whether differences in such capital help explain differences in productivity performance among countries. Their results indicate that while agricultural TFP growth in OECD countries has remained constant or slightly declined, TFP growth in developing and transition economies accelerated in the 1990s. Among developing countries, they find a strong, positive relationship between "technology capital" (research and education capacities, primarily) and long-run agricultural TFP growth.

The other four papers of this volume focus on the productivity growth experience of particular countries or regions. Jin, Ma, Huang, Hu and Rozelle use a stochastic production frontier approach to measure TFP growth for each of 23 commodities in Chinese agriculture, and decompose TFP growth into the shares due to technical change and efficiency improvement. Their results give evidence of broad-based and rapid productivity growth in Chinese agriculture, especially since 1990, and attribute most of this growth to technical change. They also find evidence of considerable disequilibrium in the Chinese agricultural sector and rising technical inefficiency during this period of rapid structural change in the economy since 1990.

Nin Pratt, Yu and Fan use a non-parametric Malmquist index to compare agricultural TFP growth between India and China. Their results show that both countries accelerated agricultural TFP growth following policy and institutional reforms. However, China's agricultural TFP

\footnotetext{
2 Their approach for measuring global agricultural TFP growth expands upon an earlier paper by Fuglie (2008).
}

growth acceleration was much more pronounced, which the authors attribute to more fundamental institutional changes as well as greater structural transformation of the Chinese economy.

In his study of Indonesia, Fuglie estimates a TornqvistThiel TFP index for the country's agriculture. He also finds evidence of an acceleration of agricultural TFP growth since the mid-1990s. In this case, a new source of productivity growth appears to be arising from greater diversification into high-valued and export commodities and declining reliance on growth from traditional food staples. Finally, in their broad study of productivity change in the 23 transition economies of the former Soviet Socialist Republics and Eastern Europe, Swinnen and Vranken analyze four sets of productivity indicators drawing upon both aggregate and micro-level data. Their results show how productivity growth varies between countries at various stages of the transition process, with all countries showing a decline in productivity at the beginning of the transition period and productivity recovery later on. But individual country experiences vary widely, and appear to be linked to both initial conditions and the pace of economic and institutional reforms.

\section{Decomposing sources of productivity growth: comparing China, India and Indonesia}

The studies in this volume all find evidence of accelerating agricultural productivity growth in the past decade in the three largest agricultural producing countries of Asia. In this section we make a comparative analysis of the sources of agricultural growth by decomposing growth in these countries into resource expansion and productivity components. We also examine the contribution of human capital augmentation to farmers' productivity. However, in order to make the comparison more meaningful we compare the countries over the same time period drawing from analyses that use similar methods. Recently, Bosworth and Collins (2008) conducted a growth accounting exercise to decompose sources of economic growth in China and India between 1978 and 2004, and reported results for the agricultural as well as non-agricultural sectors. As their method is similar to Fuglie's (this volume) for Indonesia, ${ }^{3}$ we can use the results of these two studies to compare sources of growth over the same time period. Unfortunately, we are unable to include the transition economies in this comparison due to the substantial differences in methods and

\footnotetext{
${ }^{3}$ The principal difference in methods between the two studies is in constructing the aggregate input index: Bosworth and Collins (2008) assume fixed factor shares for aggregating agricultural input growth, whereas Fuglie used a moving average of factor shares to construct a Tornqvist-Thiel growth index.
} 
period of analysis in the information currently available to us.

Table 1 shows the results of this growth decomposition exercise for the three Asian countries. Agricultural output during 1978-2004 grew most rapidly in China (4.6 percent per year) and nearly as rapidly in Indonesia (4.0 percent per year) with India trailing behind but still impressively at 2.5 percent output growth per year. We then decompose the sources of output growth in two ways: first, we divide this growth into the part due to resource (input) expansion and the part due to TFP; and second, we decompose output growth into growth in the agricultural labor force and output per worker. Growth in farm output per worker is further decomposed into growth in cropland per worker, growth in other nonland inputs per worker, improvement in average schooling of farm workers, and growth in TFP.

China and Indonesia showed similar rates of growth in inputs as well as TFP, both of which were substantially higher than in India. Growth in resource productivity (TFP) accounted for about 40 percent of total output growth in China and Indonesia and about 30 percent in India, with the share due to TFP increasing over time. This growth decomposition is consistent with differences in resource endowments among the three countries: While China and India appeared to be facing severe land constraints, Indonesia was able to expand cropland per farm worker due to continued availability of land suitable for agriculture in some of its large islands such as Kalimantan and Sumatra. China and Indonesia also reduced the rate of growth in their rural populations, while in India the agricultural labor force expanded by over one percent per year. Output per worker grew rapidly in China and Indonesia, which also experienced a sharp decline in national poverty rates (by about 30 percent, compared with only a seven percent reduction in India). The sources of labor productivity growth in China were primarily increases in nonland capital per worker and TFP. In Indonesia, on the other hand, the area cultivated per worker grew and contributed significantly to growth. India experienced a reduction in cropland per worker as the farm labor force expanded faster than new cropland could be brought into production. All countries were able to increase the average schooling level of their work forces, which raised farm labor productivity by $0.2-0.3$ percent per year in the three countries.

Table 1 Sources of growth in agriculture in China, India and Indonesia, 1978-2004

\begin{tabular}{|c|c|c|c|}
\hline & Average & ate $(\%), 19$ & \\
\hline & China & India & Indonesia \\
\hline Total output & 4.60 & 2.50 & 4.03 \\
\hline Total inputs & 2.80 & 1.70 & 2.33 \\
\hline Total factor productivity (TFP) & 1.80 & 0.80 & 1.70 \\
\hline Workers* & 0.30 & 1.10 & 0.80 \\
\hline Output/worker & 4.30 & 1.40 & 3.24 \\
\hline Cropland/worker & 0.00 & -0.10 & 0.46 \\
\hline Capital/worker & 2.30 & 0.40 & 0.83 \\
\hline Education (schooling) & 0.20 & 0.30 & 0.25 \\
\hline TFP & 1.80 & 0.80 & 1.70 \\
\hline Percent reduction in poverty, mid 1980 s to $2001-03^{\wedge}$ & 30.0 & 7.0 & 31.6 \\
\hline Agricultural research spending as percentage of agricultural GD & & & \\
\hline $1971-75$ & 0.36 & 0.22 & 0.24 \\
\hline 2001-03 & 0.49 & 0.32 & 0.21 \\
\hline Periods of major agricultural policy or institutional reforms $\mathrm{s}^{\wedge \wedge \wedge}$ & 1979-82 & - & 1966-69 \\
\hline & & & 1997-98 \\
\hline Periods of major macroeconomic reforms $s^{\wedge \wedge \wedge}$ & 1977-78 & 1991-94 & $1983-88$ \\
\hline & 1984-92 & & 1997-98 \\
\hline
\end{tabular}

* The number of agricultural workers is measured in constant-quality units after adjusting for changes in the average years of schooling of the national labor force. Capital inputs include animals, machinery, seed, feed, and fertilizer

$\wedge$ Poverty is measured as the percentage of the national population subsisting on less than PPP\$2/day (World Bank 2007)

$\wedge^{\wedge}$ Sources for public agricultural research spending as a percentage of agricultural GDP are: Indonesia (Fuglie and Piggott 2006), India (Pal and Byerlee 2006); and China (Fan et al. 2006)

$\wedge \wedge \wedge$ Descriptions of major agricultural and macroeconomic reforms can be found in Nin-Pratt et al. (this volume) for India and China and in Fuglie and Piggott (2006) for Indonesia

Source of output, input and productivity growth rates: Fuglie (this volume) for Indonesia and Bosworth and Collins (2008) for India and China 
The final rows of Table 1 indicate the public policies in the three countries which the country studies in this volume identified as major determinants of productivity. Importantly, between 1980 and 2000, both China and India increased agricultural R\&D spending relative to the size of the agricultural sector, while in Indonesia the agricultural R\&D to GDP ratio was substantially lower and slightly declined over time. The papers in this volume by Jin et al. and Nin-Pratt et al. report on the high productivity of agricultural research in China and India and its substantial contribution to productivity growth in these countries, while Fuglie (this volume) contends that Indonesia's gain in TFP was achieved first, through adoption of "Green Revolution" food crop varieties (primarily in the 1980s), and second, through diversification into higher-valued agricultural commodities (especially since the mid 1990s). There is little evidence that technological improvements were sustained in Indonesia once the high-yielding crop varieties became widely adopted.

Of considerable importance in all three countries were institutional and policy reforms that strengthened peasant agriculture and liberalized markets. The most dramatic of these reforms was probably the dismantling of communes in favor of household-based farming in China during 197881. This was followed by economic and market reforms that improved incentives, encouraged diversification and made manufactured goods more widely available. India implemented a series of market reforms in the 1990s that, while primarily directed at manufacturing, also have had a positive effect on agriculture. Indonesia underwent a major economic shock during the 1997-98 Asian Financial Crisis, but the currency devaluation and liberalization of agricultural trade which followed gave a strong impetus to exports. Indonesia has emerged as a large net exporter of agricultural commodities, especially plantation crops, forest products and fish, although it continues to import grains. The institutional and policy reforms in these Asian countries raised productivity growth by creating incentives for farmers to allocate resources more efficiently and exploiting their sectoral comparative advantage. This has proved to be a pivotal source of productivity growth in the agricultural sectors of these countries.

\section{References}

Alston JM, Beddow JM, Pardey PG (2009) Mendel versus Malthus: research, productivity and food prices in the long run. InSTePP Paper 09-01, University of Minnesota

Bosworth B, Collins SM (2008) Accounting for growth: comparing China and India. J Econ Perspect 22:45-66

Fan S, Qian K, Zhang X (2006) China: an unfinished reform agenda. In: Pardey PG, Alston JM, Piggott RR (eds) Agricultural R\&D in the developing world: too little, too late? International food policy research institute. Washington, DC, pp 29-64

Fuglie KO (2008) Is a slowdown in agricultural productivity growth contributing to the rise in commodity prices? Agric Econ 39: $431-441$

Fuglie KO, Piggott RR (2006) Indonesia: coping with economic and political instability. In: Pardey PG, Alston JM, Piggott RR (eds) Agricultural R\&D in the developing world: too little, too late? International food policy research institute. Washington, DC, pp 65-104

Ludena CE, Hertel TW, Preckel PV, Foster K, Nin A (2007) Productivity growth and convergence in crop, ruminant, and nonruminant production: measurement and forecasts. Agric Econ 37:1-17

Pal S, Byerlee D (2006) India: the funding and organization of agricultural R\&D-evolution and emerging policy issues. In: Pardey PG, Alston JM, Piggott RR (eds) Agricultural R\&D in the developing world: too little, too late? International food policy research institute. Washington, DC, pp 155-194

World Bank (2007) WDI Online. http://publications.worldbank.org/ WDI/. World Bank, Washington, DC. Accessed Feb 2007 